\title{
Microbiota and skin defense peptides may facilitate coexistence of two sympatric Andean frog species with a lethal pathogen
}

\author{
Sandra V. Flechas $\mathbb{1}^{1,9} \cdot$ Alejandro Acosta-González ${ }^{2}$ - Laura A. Escobar ${ }^{3} \cdot$ Jordan G. Kueneman $^{4,5}$. \\ Zilpa Adriana Sánchez-Quitian ${ }^{3,6}$. Claudia M. Parra-Giraldo ${ }^{3}$ - Louise A. Rollins-Smith ${ }^{7}$ - Laura K. Reinert ${ }^{7}$. \\ Vance T. Vredenburg ${ }^{8} \cdot$ Adolfo Amézquita $^{1} \cdot$ Douglas C. Woodhams ${ }^{4,5}$
}

Received: 7 March 2018 / Revised: 21 August 2018 / Accepted: 23 August 2018 / Published online: 25 September 2018

(c) International Society for Microbial Ecology 2018

\begin{abstract}
Management of hyper-virulent generalist pathogens is an emergent global challenge, yet for most disease systems we lack a basic understanding as to why some host species suffer mass mortalities, while others resist epizootics. We studied two sympatric species of frogs from the Colombian Andes, which coexist with the amphibian pathogen Batrachochytrium dendrobatidis (Bd), to understand why some species did not succumb to the infection. We found high Bd prevalence in juveniles for both species, yet infection intensities remained low. We also found that bacterial community composition and host defense peptides are specific to amphibian life stages. We detected abundant Bd-inhibitory skin bacteria across life stages and Bd-inhibitory defense peptides post-metamorphosis in both species. Bd-inhibitory bacteria were proportionally more abundant in adults of both species than in earlier developmental stages. We tested for activity of peptides against the skin microbiota and found that in general peptides did not negatively affect bacterial growth and in some instances facilitated growth. Our results suggest that symbiotic bacteria and antimicrobial peptides may be co-selected for, and that together they contribute to the ability of Andean amphibian species to coexist with the global pandemic lineage of $\mathrm{Bd}$.
\end{abstract}

\section{Introduction}

All living organisms establish symbiotic relationships with microbes, and together, they are considered by some authors to be a unit of natural selection [1]. Macroorganisms offer selective microhabitats for the establishment of complex microbial communities. Within these, microorganisms

Electronic supplementary material The online version of this article (https://doi.org/10.1038/s41396-018-0284-9) contains supplementary material, which is available to authorized users.

Sandra V. Flechas

vickyflechas@gmail.com

1 Department of Biological Sciences, Universidad de los Andes, Bogotá 111711, Colombia

2 Faculty of Engineering, Universidad de la Sabana, Chía, AA 53753, Colombia

3 Department of Microbiology, Faculty of Sciences, Pontificia Universidad Javeriana, Bogotá AA 56710, Colombia

4 Biology Department, University of Massachusetts Boston, Boston, MA 02125, USA influence the health status of their hosts through interactions ranging from mutualistic to parasitic [2,3]. Microorganisms play an important role in many processes including food transformation, nutrient uptake, defense against pathogens, and may also be involved in predisposition to different diseases [2, 4-6]. Indeed, symbionts may influence the expression of phenotypes that were traditionally attributed entirely to the host $[7,8]$. Consequently, a better understanding of the microbiota and their dynamics, as well as the factors determining the establishment and structure of

5 Smithsonian Tropical Research Institute, Panama Apartado 084303092, Republic of Panama

6 Environmental Management Group, Department of Biology and Microbiology, Universidad de Boyacá, Tunja 150000003, Colombia

7 Department of Pathology, Microbiology and Immunology, Vanderbilt University, School of Medicine, Nashville, TN 37232, USA

8 Department of Biology, San Francisco State University, San Francisco, CA 94132-1722, USA

9 Present address: Instituto de Investigación de Recursos Biológicos Alexander von Humboldt, Bogotá, Colombia 
bacterial assemblages could lead to control strategies for a great variety of diseases [9].

Pathogenic fungi are currently recognized as a major threat to animal health [10]. One of the most dramatic examples of population declines is due to the pathogenic fungus Batrachochytrium dendrobatidis (Bd) [11], which is the causative agent of chytridiomycosis [12]. This disease has strongly impacted amphibian communities [13, 14], causing die-offs and collapses across entire amphibian communities at a scale never before recorded in history [15]. Amphibian species have been affected by Bd in almost every continent [13]. However, despite the catastrophic declines, some species seem to tolerate and may coexist with Bd without displaying clinical signs and are considered asymptomatic carriers $[16,17]$. This differential response to Bd infection might be related to host, environment, and pathogen characteristics [18-21].

Symbiotic bacteria and skin defense peptides (often called antimicrobial peptides, AMPs) in the skin mucous layer are among the primary barriers impeding cutaneous colonization by the pathogenic fungus [22-24]. Many bacterial isolates are capable of inhibiting the growth of $\mathrm{Bd}$ [19, 25-28]. Moreover, the use of beneficial microorganisms in probiotic therapy via bioaugmentation has been considered one of the most promising strategies for treatment of infected animals and prevention of amphibian population declines caused by $\mathrm{Bd}$ [29-31]. In addition, other studies have shown that purified peptides from a wide range of amphibian species inhibit Bd growth under laboratory conditions [32, 33] (reviewed in [34-36]). Anti$\mathrm{Bd}$ abilities differ among peptides (reviewed in [34-36]), and the composition of skin defense peptides in each amphibian species may predict whether they can or cannot resist chytridiomycosis under natural conditions [23] (reviewed in [22]). Despite the large body of evidence supporting the importance of symbiotic bacteria and skin peptides as defense mechanisms against pathogens including $\mathrm{Bd}$, factors determining the structure of bacterial communities remain unclear.

Here, we aimed to understand the microbial component of resistance to $\mathrm{Bd}$ infection as well as the role of skin peptides as both a direct defense against $\mathrm{Bd}$ and as an indirect defense influencing microbial assemblages. We studied two sympatric species of frogs from the Colombian Andes, the high Andean frog (Dendropsophus labialis, Hylidae) and the rocket frog (Rheobates palmatus, Aromobatidae). Although, Bd prevalence is high in both species, juveniles appeared to be more infected than tadpoles or adults; however, there is no record of population declines or clinical signs of chytridiomycosis. We hypothesized that differences in Bd prevalence among life stages were associated with skin peptides and skin bacteria. Both species in this study share the same habitat for reproduction, which could potentially mean that both species harbor similar skin microbial assemblages. Thus, we describe the microbial community occurring on the skin of these species, as well as their immediate environment by using 16S rRNA sequencing. We identified the culturable portion of the skin microbiota with antifungal activity and we tested skin defense peptides against $\mathrm{Bd}$ to better understand the contribution of each defense in this system of "Bd-tolerant" frogs. Using a database of anti-Bd bacteria, we examined the proportion of bacterial sequences associated with inhibitory OTUs (Operational Taxonomic Units). Lastly, we tested skin peptides to determine if skin secretions are restricting microbial communities, with the hypothesis that evolution may have led to host peptides that support antifungal bacterial communities on the skin of these common Bd-tolerant amphibians. We provide key information on how microbial-pathogen interactions differ across life stages, and how changes in bacterial community composition may affect the response to Bd infection.

\section{Methods}

\section{Sample collection}

We studied two sympatric species of frogs from the Colombian Andes, Dendropsophus labialis (Hylidae) and Rheobates palmatus (Aromobatidae). Individuals of both species were sampled in a pond located near Ubaque, Departamento de Cundinamarca, Colombia $\left(04^{\circ} 26^{\prime} 12^{\prime \prime} \mathrm{N}\right.$, $73^{\circ} 55^{\prime} 10^{\prime \prime} \mathrm{W}$, at $1970 \mathrm{~m}$ ). We visited the site 8 times between 2009 and 2016 (Table 1). We aimed to test whether variations in skin defense peptides and microbiota composition between life stages and species are correlated with $\mathrm{Bd}$ prevalence and infection intensity and to determine the role of skin peptides as modulators of the bacterial communities. To address our aims we used a fourfold approach: (1) All animals were swabbed for $\mathrm{Bd}$ diagnosis and zoospores quantification, (2) skin swab samples from a subset of individuals and from the environment were used to characterize bacterial communities using targeted amplicon sequencing with Illumina MiSeq, (3) culturable bacteria were identified by mass spectrometry and 16S rRNA sequencing and tested against Bd in order to identify strains with antifungal capacity, and (4) skin defense peptides were tested against $\mathrm{Bd}$ and bacteria through growth inhibition assays (see Supplementary Material for additional details).

\section{Batrachochytrium dendrobatidis diagnosis and quantification}

For regular PCR, DNA was extracted using GeneReleaser ${ }^{\circledast}$ (Bioventures Inc., Carlsbad, California, USA). The PCR 
Table 1 Summary of sampling by species of frog and date

\begin{tabular}{|c|c|c|c|c|c|c|c|}
\hline \multirow[b]{2}{*}{ Species } & \multirow[b]{2}{*}{$\begin{array}{l}\text { Date of } \\
\text { sampling }\end{array}$} & \multirow[b]{2}{*}{$\begin{array}{l}\text { Sampled } \\
\text { individuals }\end{array}$} & \multicolumn{5}{|c|}{ No. of individuals used for: } \\
\hline & & & $\begin{array}{l}\text { End-point } \\
\text { PCR } \\
\text { detection }\end{array}$ & $\begin{array}{l}\text { qPCR } \\
\text { detection }\end{array}$ & $\begin{array}{l}16 \mathrm{~S} \\
\text { barcode }\end{array}$ & $\begin{array}{l}\text { Culture } \\
\text { dependent }\end{array}$ & $\begin{array}{l}\text { Peptide } \\
\text { analysis }\end{array}$ \\
\hline \multirow{9}{*}{$\begin{array}{l}\text { Dendropsophus } \\
\text { labialis }\end{array}$} & May 2009 & 23 & 23 & - & - & - & - \\
\hline & Apr 2010 & 6 & 6 & - & - & - & - \\
\hline & Sep 2011 & 12 & 12 & - & - & - & - \\
\hline & Jul 2014 & 18 & - & 18 & 18 & - & - \\
\hline & Aug 2014 & 9 & - & 9 & - & - & - \\
\hline & Nov 2014 & 3 & - & 3 & - & - & - \\
\hline & Apr 2015 & 10 & - & 10 & - & 9 & - \\
\hline & Feb 2016 & 17 & - & 16 & - & - & 17 \\
\hline & Total & 98 & 41 & 56 & 18 & 9 & 17 \\
\hline \multirow{9}{*}{$\begin{array}{l}\text { Rheobates } \\
\text { palmatus }\end{array}$} & May 2009 & 43 & 43 & - & - & - & - \\
\hline & Apr 2010 & 56 & 56 & - & - & - & - \\
\hline & Sep 2011 & 31 & 31 & - & - & - & - \\
\hline & Jul 2014 & 26 & - & 26 & 26 & - & - \\
\hline & Aug 2014 & 9 & - & 9 & - & - & - \\
\hline & Nov 2014 & 8 & - & 8 & - & - & - \\
\hline & Apr 2015 & 16 & - & 16 & - & 15 & - \\
\hline & Feb 2016 & 26 & - & 20 & - & - & 26 \\
\hline & Total & 215 & 130 & 79 & 26 & 15 & 26 \\
\hline
\end{tabular}

Eight field trips were conducted to the same pond in Ubaque, Cundinamarca, Colombia. For each trip, the table provides the collection date and total number of frogs sampled. Each sample was analyzed by one or more of five methods, including diagnostic tests of $B d$ infection by end-point PCR or quantitative PCR, 16S metagenomic survey of bacterial diversity using an Illumina MiSeq, isolation of culturable bacteria, and extraction of antimicrobial peptides. Details are provided in the Methods section reactions were performed following the protocol described by Annis et al. [37]. For the qPCR Bd assay, DNA was extracted using PrepMan Ultra (Thermo-Fisher Scientific, Waltham, Massachusetts, USA). Extractions and qPCRs were performed following the methods described by Hyatt et al. [38] and Boyle et al. [39]. To quantify infection intensity, we used DNA standards of known concentrations from isolate Bd-GPL (id \# CJB57-(4)-p6) and negative controls (see Supplementary Material for additional details).

\section{DNA extraction, amplification, and sequencing of $16 S$ rRNA}

DNA for microbial community analysis was extracted from each of the 54 swabs samples (44 from frogs and 10 from water) using the Qiagen DNeasy blood \& tissue kit (Valencia, California, USA) following the manufacturer's protocol that was slightly modified. We obtained 16S rRNA gene amplicons using the hypervariable V3-V4 region. PCR reactions were performed in a MJ Research (PTC-200, Hercules, California, USA) and products were visualized by electrophoresis in a $1.2 \%$ agarose gel stained with ethidium bromide. We quantified libraries using KAPA Illumina Quantification Kits. PCR products were pooled in equimolar quantities before sequencing on an Illumina MiSeq system (llumina, Inc., San Diego, California, USA; see Supplementary Material for details). Sequence data are deposited in Genbank (BioProject: SRP149982).

\section{Sequence data processing}

The 16S rRNA sequences were demultiplexed and quality filtered using quantitative insights into microbial ecology (QIIME) 1.9.1 [40]. Filtered sequences were clustered into operational taxonomic units (OTUs) using the deblur protocol workflow outlined in Amir et al. [41]. Deblur is a greedy deconvolution algorithm that removes lowabundance sequences and resolves related OTUs based on error profiles. This protocol is more conservative than previous approaches in assigning OTU ids, which returns a more accurate estimate of diversity and higher confidence in taxonomic assignments. Using this protocol, we detected a total of 37,167 unique OTUs and a median of 16,423 sequences per sample. We rarefied our dataset to 7,065 sequences per sample to provide sufficient sequence depth within a sample, as well as to retain sufficient numbers of samples for comparison. All samples with sequences abundances below 7,065 were excluded. To explore the 
distribution of bacterial taxa that match known Bdinhibitory taxa, we picked OTUs against the antifungal isolates database [27], using the same OTU picking methodology. First, we trimmed the sequences from anti-Bd isolates in the database to $150 \mathrm{bp}$. This was then set as the reference database by which to compare our dataset, retaining only $100 \%$ matches. Analyses of alpha and beta diversity were conducted in QIIME 1.9.1 and visualizations were generated with R [42] using RStudio. Statistical analyses including LEfSe [43] analysis of relative abundance of microbial taxa among life stages are described below.

\section{Characterization of culturable bacteria}

To characterize the culturable bacteria, we followed the isolation procedures described by Flechas et al. [44]. Isolated morphotypes were identified by mass spectrometry with MALDI-TOF (Matrix-assisted laser desorption/ionization time of flight) and Biotyper BRUKER (Billerica, Massachusetts, USA). The profiles were visualized with the software FlexControl (version 3.0) and MALDI Biotyper RTC. For calibration and as a positive control, we used a Bacterial Test Standard (BTS) Escherichia coli (DH5 $\alpha$ ) (Bruker Daltonik GmbH, Bremen, Germany) proteomic profile. Isolates that we failed to identify through mass spectrometry were identified by sequencing the 16S rRNA gene (see Supplementary Materials for additional details).

\section{The antifungal role of the cutaneous symbiotic bacteria}

To determine the capabilities of skin bacteria to inhibit $\mathrm{Bd}$, axenic cultures were grown in TGhL broth at $0.5 \mathrm{X}(5 \mathrm{~g}$ tryptone, $2 \mathrm{~g}$ gelatin hydrolisate, $1 \mathrm{~g}$ lactose, and $1000 \mathrm{~mL}$ distilled water) in $15-\mathrm{mL}$ falcon tubes. Cultures were shaken at $250 \mathrm{rpm}$ for $48 \mathrm{~h}$ at $25^{\circ} \mathrm{C}$. Samples were centrifuged at $6000 \mathrm{rpm}$ for $5 \mathrm{~min}$ at $4{ }^{\circ} \mathrm{C}$. The supernatant was passed through a $0.22-\mu \mathrm{m}$ syringe filter. We tested each bacterial morphotype against $\mathrm{Bd}$. We set up challenge assays in 96well microplates (TPP ${ }^{\circledR}$; Sigma, St. Louis, Missouri, USA), as described previously by Bell et al. [45]. Microplates were incubated at $23{ }^{\circ} \mathrm{C}$ during 7 days. Changes in optical density were measured at $490 \mathrm{~nm}$ absorbance every $24 \mathrm{~h}$ for 7 days using a BIO-RAD 680 (Hercules, California, USA) spectrophotometer.

\section{Effect of antimicrobial peptides on Bd and skin bacterial growth}

In order to induce skin peptides release, adult frogs were injected with $40 \mathrm{nmol}$ norepinephrine bitartrate (NE; Sigma, St. Louis, Missouri, USA) per gram body mass. Tadpoles were immersed for $15 \mathrm{~min}$ in a solution of $100 \mu \mathrm{M}$ norepinephrine. Peptides were concentrated, partially purified, and re-suspended following the protocol described by Daum et al. [46]. To accurately determine peptide sample concentration, we used a Micro BCA protein assay kit (Thermo-Fisher Scientific, Waltham, Massachusetts, USA) with bradykinin (Sigma, St. Louis, Missouri, USA) as a standard. Skin defense peptides from each individual (final concentration $100 \mu \mathrm{g} / \mathrm{mL}$ ) were tested against $\mathrm{Bd}$ strain EV001 [47] in triplicate at a concentration of $2 \times 10^{7}$ zoospores following the methods previously described [35, 46]. Zoospores were harvested using filters of 10 micron pore size (Chemrus, Holliston, Massachusetts, USA).

\section{Identification of antimicrobial peptides in skin secretions}

To identify peptide presence in the skin secretions of adults and tadpoles from both species and to confirm the molecular weight of peptides, we used MALDI-TOF mass spectrometry following the protocol described by Holden et al. [48].

\section{Data analysis}

To determine if there are differences in Bd prevalence and infection intensity between $D$. labialis and $R$. palmatus and among life stages in each species, we performed a Student's $t$ test and a nested ANOVA, respectively. To determine the prevalence of infection, we used the whole dataset including end-point PCR and qPCR results. For infection intensity analyses, we used the subset of samples that were run using qPCR. Since our dataset did not meet the assumptions of normal distribution before running the test, we transformed the data and checked for equal variances using the ShapiroWilk test. Venn diagrams were created with the program Venny [49] and were used to visualize: (1) the number of bacterial morphotypes with anti-Bd activity exclusive in each category and shared among life stages of both frog species and (2) the number of OTUs that were shared among life stages and the water. In this case we compared one species at a time.

Measures of alpha diversity for the bacterial community on each individual were calculated using the Shannon diversity index. We used both sets of data, the culturable bacteria and the bacterial $16 \mathrm{~S}$ barcodes from Illumina MiSeq. To test for significant differences in alpha diversity, we first checked for normality of data within categories and equal variances among categories using the Shapiro-Wilk test. In addition, we inspected the distribution histograms to confirm departures from normality. We calculated Shannon-Weiner diversity index for each individual using the 'diversity' function in the 'vegan' package [50]. We tested for differences in the relative abundance of microbial taxa among life stages of both species with the linear 
Table 2 Batrachochytrium dendrobatidis prevalence among life stages in two amphibian species

\begin{tabular}{lllll}
\hline Species & Life stage & Total sampled & $B d$ positives & Prevalence CI (95\%) \\
\hline Dendropsophus labialis & Tadpole & 14 & 0 & $0(0-23.1)$ \\
& Juvenile & 10 & 4 & $40(12.1-73.7)$ \\
& Adult & 73 & 30 & $41(29.7-53.2)$ \\
& Total & 97 & 34 & $35(25.6-45.4)$ \\
Rheobates palmatus & Tadpole & 24 & 4 & $16.6(4.7-37.3)$ \\
& Juvenile & 94 & 44 & $46.8(36.4-57.3)$ \\
& Adult & 91 & 14 & $15.3(8.6-24.4)$ \\
& Total & 209 & 6 & $29.6(23.5-36.3)$ \\
\hline
\end{tabular}

Prevalence CI 95\% prevalence of infection

In parentheses are the Bayesian credible intervals based on $95 \%$ confidence. Bold numbers indicate summaries per species discriminant analysis (LDA) effect size (LEfSe) method [43]. Weighted Unifrac distance metric was used in beta diversity analyses, and statistical differences between sample types were calculated with Adonis.

The effect of peptides on Bd growth was assessed using a one-sample $t$ test. Then to examine the effect of skin peptides on bacterial growth, we calculated the difference between $48 \mathrm{~h}$ and $0 \mathrm{~h}$ and we compared against the OD values from controls. One-way ANOVA and post hoc Tukey's test were conducted to determine if there was a significant effect of the peptide source on the bacterial growth.

\section{Results}

\section{Batrachochytrium dendrobatidis diagnosis and quantification}

We procured skin swab samples of 306 individuals, 97 from Dendropsophus labialis and 209 from Rheobates palmatus, and diagnosed $B d$ infection (Table 1). Ninety-six individuals were diagnosed as positive for $\mathrm{Bd}(31.3 \%, \mathrm{CI}=26.2-$ $36.8 \%$ ) using both diagnostic techniques (qPCR and endpoint PCR; Table 2). We found that Bd prevalence was higher in juveniles, where $46.1 \%$ of individuals sampled were positive for the pathogen, compared with $26.8 \%$ of adults and $10.5 \%$ of tadpoles $\left(\chi_{\mathrm{df}=2}^{2}=19.8, P<0.05\right)$. Our results also revealed that infection prevalence was similar in both amphibian species $\left(\chi_{\mathrm{df}=1}^{2}=0.66, P=0.416\right)$. Infection intensity (as zoospore equivalents, ZE) ranged from 0.062 to $27,676(\bar{X}=1491 \mathrm{ZE}, \mathrm{SD}=6171)$ in D. labialis and from 0.1 to $1240(\bar{X}=119 \mathrm{ZE}, \mathrm{SD}=322)$ in $R$. palmatus. The D. labialis individual with 27,676 zoospores was an outlier (range without the outlier is 0.062-1422 ZE). The zoospore loads detected here, aside from the outlier, are within the range at which hosts are resisting the infection, rather than tolerating high infection loads that typically cause clinical signs and skin damage in susceptible host species [51]. We did not find differences in zoospore loads either among life stages nested within species $(\mathrm{F}=0.5799$, $P=0.4512)$ or between species $(\mathrm{F}=0.135, P=0.714)$.

\section{Skin bacterial community composition using bacterial $16 \mathrm{~S}$ barcode sequencing}

After quality control and rarefaction, we used 16 samples from D. labialis (adult $n=8$, juveniles $n=2$, and tadpole $n=6$ ), 21 samples from $R$. palmatus (adult $n=7$, juvenile $n=5$, and tadpoles $n=9$ ), and nine samples from pond water to examine alpha diversity (or species richness). We found no significant differences in alpha diversity across amphibian species or life stages (Fig. 1). We detected marginal differences in community composition between species when comparing each species, including tadpoles as well as excluding tadpoles (see Supplementary Material). All life stages held significantly lower diversity than the water they inhabited (ANOVA; $\mathrm{df}=6, \mathrm{~F}=7.924, P<$ 0.0001 ), and amphibian skin community structure was also different from the microbial community of the pond water (Supplementary Figure 1). Analysis of post-metamorphic host microbial communities (beta diversity) did not indicate strong differences related to $\mathrm{Bd}$ infection status (weighted Unifrac Adonis F-R ${ }^{2}=0.07, P<0.137$; unweighted Unifrac Adonis $\left.\quad \mathrm{F}^{-\mathrm{R}^{2}}=0.083, \quad P<0.001\right)$. Furthermore, FDRcorrected group significance test did not identify bacterial OTUs that strongly distinguish infected individuals from the uninfected, however, two OTUs in the genus Polynucleobacter (Oxalobacteraceae) had means of several hundred sequences detected on uninfected individuals compared to zero sequences detected on infected individuals. Analysis of host microbial communities did show significant differences within species by host life stage (unweighted Unifrac Adonis F-R ${ }^{2}=0.26, P<0.001$ for $R$. palmatus and Adonis $\mathrm{F}^{2} \mathrm{R}^{2}=0.285, P<0.001$ for $D$. labialis; Fig. 2), but only $R$. palmatus displayed a 
Fig. 1 Alpha diversity (species richness) of bacterial communities in each species, life stage, and pond water. The asterisk indicates significant differences between the water and amphibian hosts

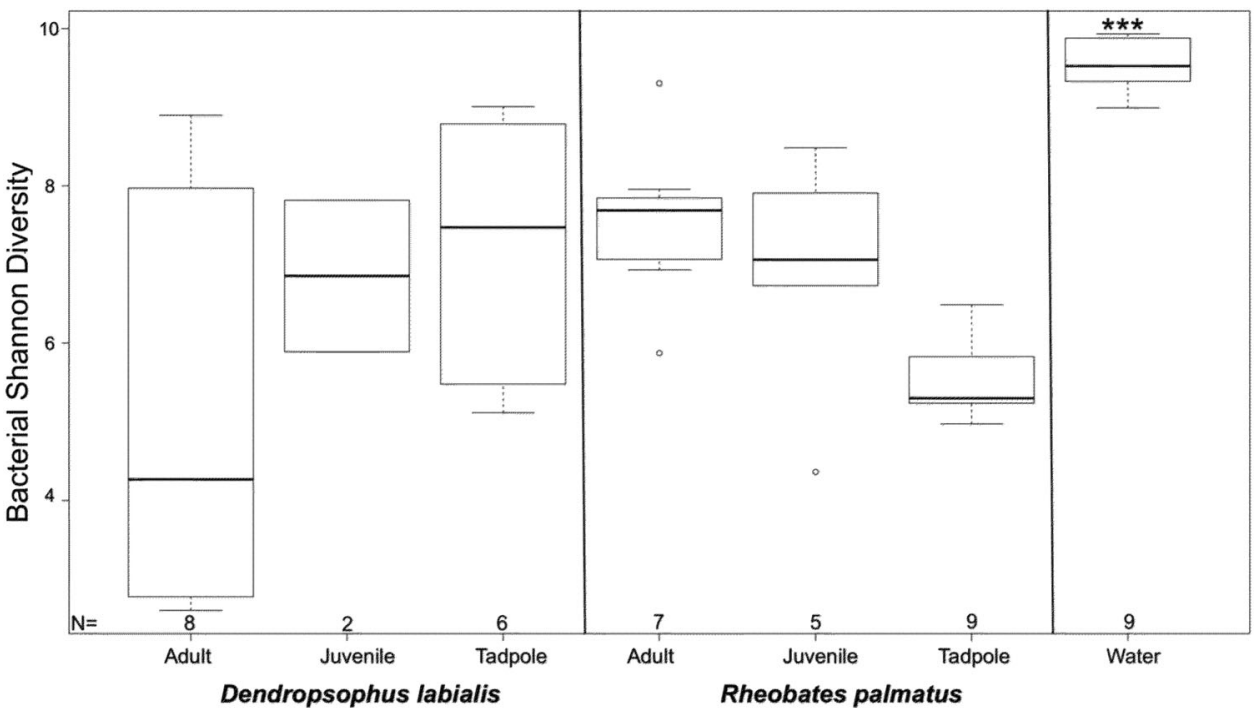

Rheobates palmatus

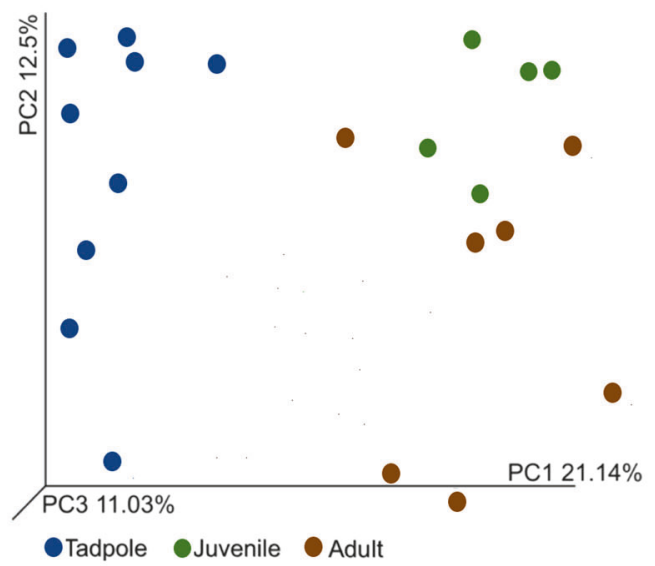

Fig. 2 Principal coordinate analysis of beta diversity of skin microbial communities for each amphibian species differentiated by life stage. Each point represents the skin bacterial community of an individual

significant difference in the composition as compared using weighted Unifrac. Life stage differences are seen in $R$. palmatus (weighted Unifrac Adonis $\mathrm{F}-\mathrm{R}^{2}=0.379, P<$ 0.001 ). Differences in weighted Unifrac were not significant for D. labialis (weighted Unifrac Adonis F- $\mathrm{R}^{2}=0.195, P<$ 0.13 ). All life stages in both species were dominated by the class Betaproteobacteria, and host life stages differed in their proportional abundance of many other taxa. In particular, in $R$. palmatus Gammaproteobacteria were present in juveniles $(5.3 \%)$ and adults $(11.4 \%)$ and almost absent in tadpoles (0.1\%) (Fig. 3, Supplementary Figure 2). According to the LEfSe analyses, Flavobacteriia increased in abundance from tadpoles (6.4\%) to adults $(39.3 \%)$ in $D$. labialis (Supplementary Figure 3, Table S1). Bacteria that match isolates known to inhibit Bd according to the public
Dendropsophus labialis

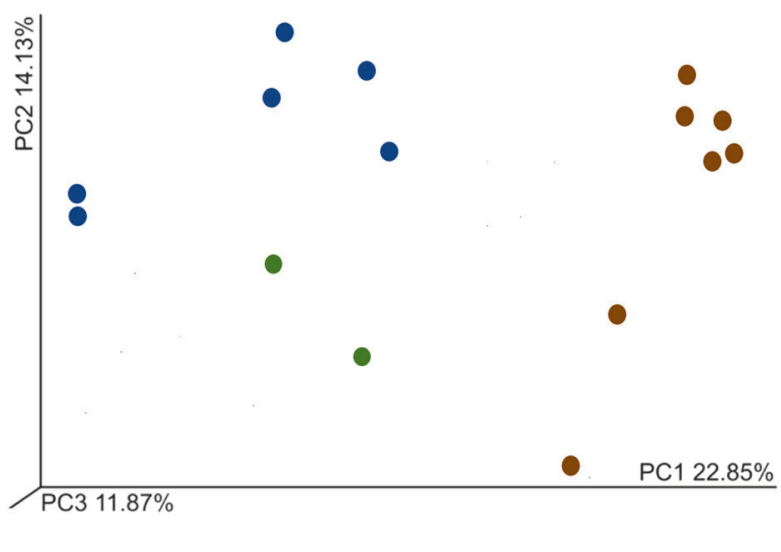

frog. Symbol and color indicate the life stage and species. Weighted Unifrac distance metric was used in beta diversity analyses

database [27] were found to be unequally distributed across life stages of each species $(R$. palmatus $=$ ANOVA; $\mathrm{df}=2$, $\mathrm{F}=4.527, P<0.0255$ and $D$. labialis ANOVA; $\mathrm{df}=2$, $\mathrm{F}=10.58, P<0.00188$ ). Our data show that the highest sequence abundance of putatively anti-Bd bacteria occurred in adults of $D$. labialis and then secondarily in adults of $R$. palmatus. The bacterial taxa that were proportionally most abundant were in classes Flavobacteriia and Betaproteobacteria (Supplementary Figure 4). For both amphibian species, we found five OTUs with more than ten sequences present on tadpoles and also on adults. Four out of five of the OTUs were shared by the two species and one is uniquely present in each species. For $R$. palmatus, the unique OTU was in the family Methylophilaceae, and for D. labialis, was in the family Xanthomonadaceae. 


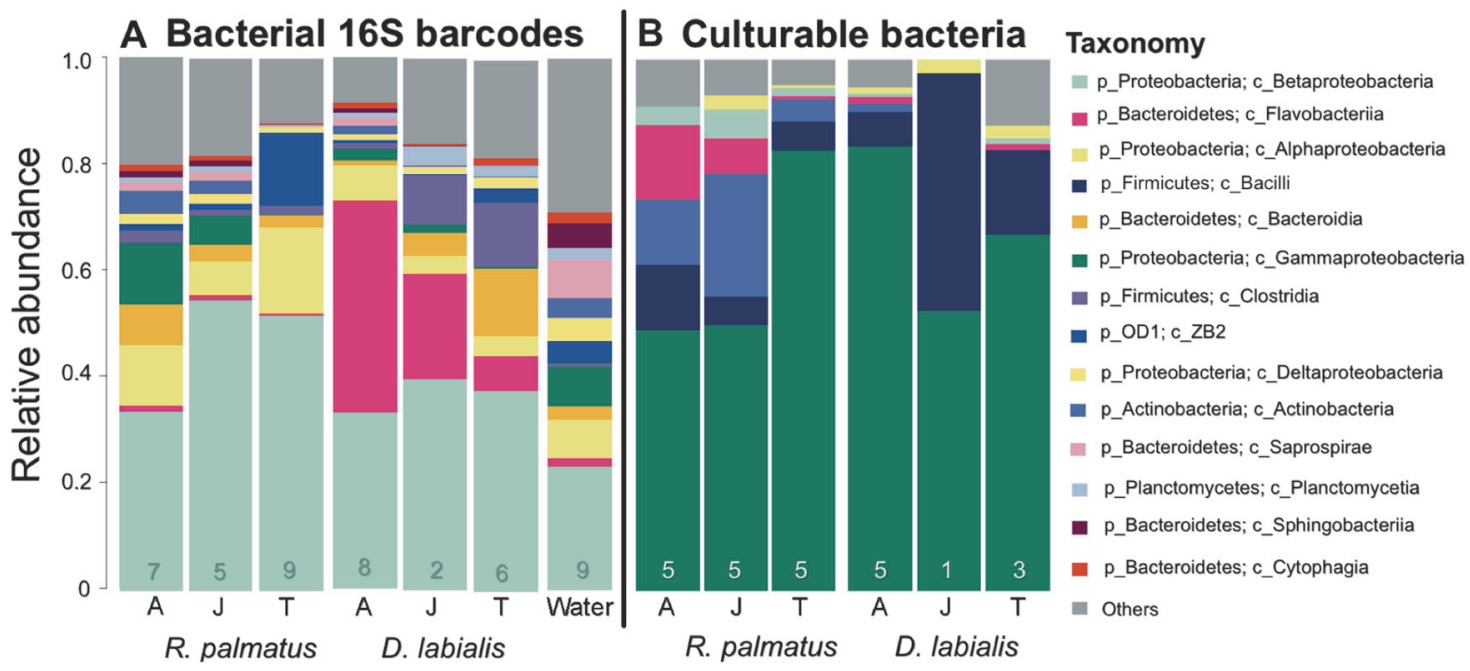

Fig. 3 Relative abundance of bacterial phyla by species and life stage. a Relative abundance of bacterial $16 \mathrm{~S}$ sequences obtained through $16 \mathrm{~S}$ sequencing of microbiota in two amphibian hosts across life stages and in pond water samples. b Relative abundance of isolates recovered through culturable-dependent techniques. The letters along the bottom indicate life stage, $\mathrm{A}$ - adult, $\mathrm{J}$-juvenile, $\mathrm{T}$ - tadpole. Numbers inside the bars denoted the number of samples per category

Chryseobacterium joostei, and Pseudomonas chlororaphis present in tadpoles, juveniles, and adults from $R$. palmatus. In the case of D. labialis, the only bacterial species shared among the three stages was B. cereus. Pseudomonas koreensis is the only bacterium that was present in both amphibian species and in all life stages.

To determine anti-Bd activity and differences in bacterial performance among amphibian species and life stages, we challenged the isolated bacteria against Bd. Given the redundancy in the isolated bacteria, we chose one bacterial isolate per life stage in each species for each cluster determined by MALDI-TOF, and therefore we only tested $25.8 \%$ of the isolates (159 from 615). We found evidence of antifungal activity in $126(80 \%)$ of the isolates, which correspond to 72 out of 100 identified species. We detected the anti-Bd activity in members of 27 genera in R. palmatus and 16 genera in D. labialis. Across life stages, the highest number of isolates with anti-Bd activity was found in tadpoles from $R$. palmatus with 31 isolates, followed by 21 in adults and 15 in juveniles. For D. labialis, we detected 21 anti-Bd bacteria in adults, 12 in tadpoles, and eight in juveniles. In addition, we found that some isolates facilitated $\mathrm{Bd}$ growth, including species from three genera for D. labialis and ten for R. palmatus (Table S3).

\section{Effect of antimicrobial peptides on the skin bacterial community composition}

Peptides were sampled from 30 tadpoles (in groups of five individuals for a total of six samples) and 20 adults of $R$. palmatus, and three tadpoles (one sample) and 16 adults of D. labialis. We found that both amphibian species secrete 

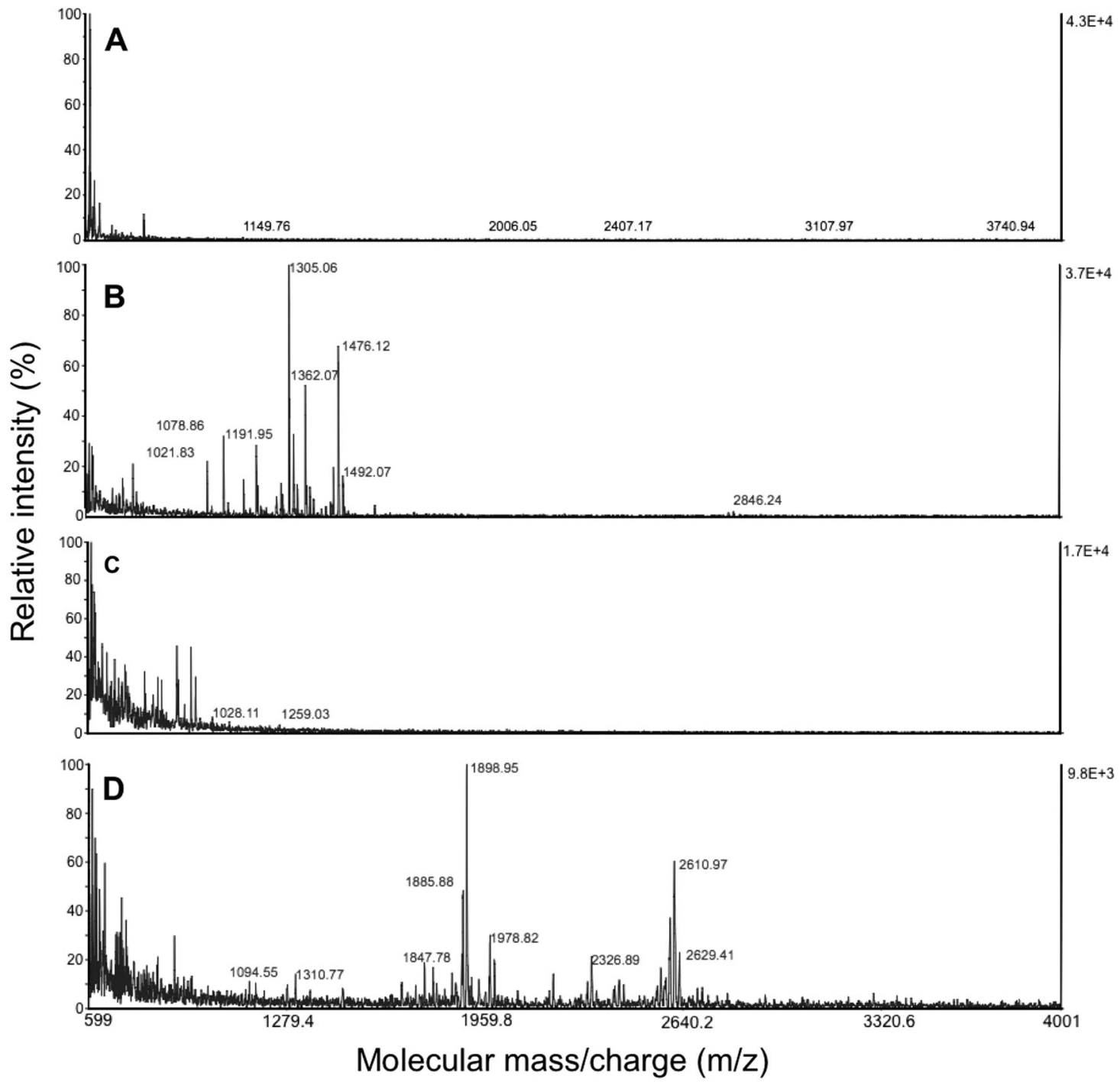

Fig. 4 MALDI-TOF mass spectrometry profiles of skin peptides. a Dendropsophus labialis — tadpole, b Dendropsophus labialis—adult, c Rheobates palmatus-tadpole, and d Rheobates palmatus-adult.

skin peptides that can inhibit Bd. Total quantities of peptides collected per species/life stage varied between 41.9 and $1918.6 \mu \mathrm{g}$ (Table S4). The species have different peptide profiles and do not express adult-type peptides as tadpoles (Fig. 4). Adult peptide profiles showed marked differences between species (Fig. 4). In D. labialis, we identified a number of peaks with mass signals between 1000 and 2000 (mass to charge ratio, $\mathrm{m} / \mathrm{z}$ ). In R. palmatus two peaks were consistently found in all samples, the first one at $1898.96 \mathrm{~m} / z$ and the second peak at $2610.98 \mathrm{~m} / \mathrm{z}$. We found that most of the natural peptide mixtures inhibited $\mathrm{Bd}$ growth at the concentration tested $(100 \mu \mathrm{g} / \mathrm{mL} ; \mathrm{t}=$ -4.0062 , df $=34, P=0.0002$; Fig. 5). Our results indicate that skin defense peptides in general do not inhibit host bacterial growth at the relatively low concentration tested here, and growth of some bacteria was facilitated by the
Note that the noise in (a) and (c) (spectra from tadpole samples) indicate a lack of peptide signals

peptides (Fig. 6). In addition, the effect of skin peptides varies with the source of the peptides and with the origin of the bacteria (Supplementary Figure 7).

\section{Discussion}

Ontogenetic changes in susceptibility have been demonstrated to occur in a number of amphibian species, in which recently metamorphosed individuals are facing a greater risk of disease due to higher infection intensities and lower immune function compared with adults $[52,53]$ (reviewed in [54]). For many species, the response of the host varies significantly depending on the life stage, suggesting that the development of the immune system including antimicrobial peptides has a key role in preventing morbidity and 


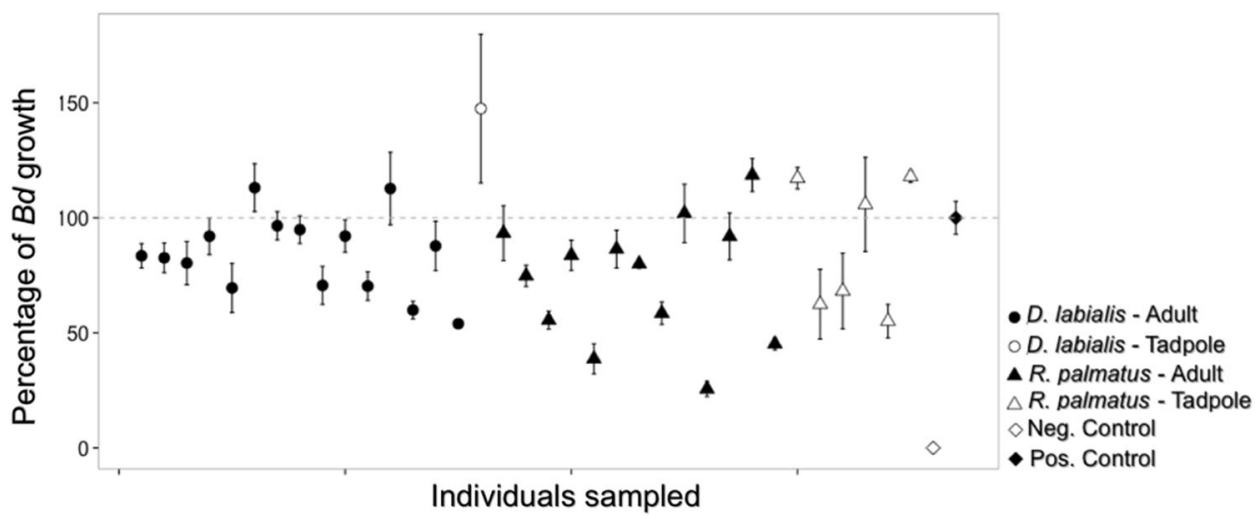

Fig. 5 Variation among frogs in the effect of their skin antimicrobial peptides on Bd growth. Peptide samples were collected from Dendropsophus labialis adults (black circles, $N=15$ ), D. labialis tadpoles (white circles, $N=1$ ), Rheobates palmatus adults (black triangles,
$N=13$ ), $R$. palmatus tadpoles (white triangles, $N=6$ ). Vertical bars indicated \pm 1 standard error. Positive control (black diamond) and negative control (white diamond) are included. The dotted line represents the growth of $\mathrm{Bd}$ in the absence of peptides
Fig. 6 Effect of antimicrobial peptides on bacterial growth. Each panel shows the proportion of affected bacteria when exposed to peptides from four different sources (adults and juveniles of Dendropsophus labialis and Rheobates palmatus). Bars represent the source of bacteria. Light gray represents the proportion of bacteria that were not significantly affected by peptides. Dark gray represents the proportion of bacteria whose growth was significantly enhanced by peptides. Black represents the proportion of bacteria that were significantly inhibited by peptides. White spaces indicate that this test was not performed
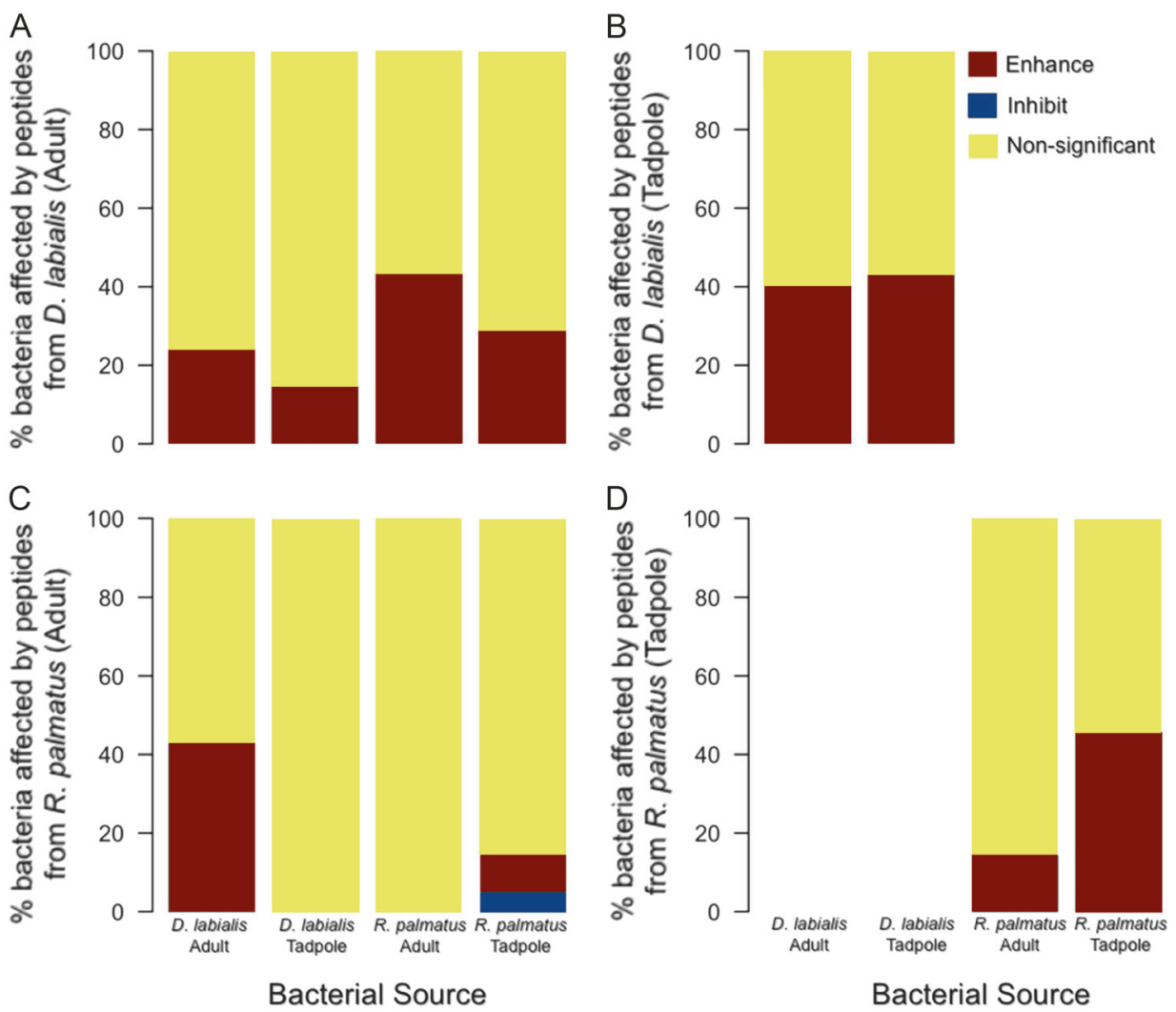

mortality $[48,55]$. Indeed, our study shows that skin peptide defenses are not present in tadpoles of these species, and a delay in peptide expression after metamorphosis may increase infection risk on recent metamorphs. Developmental changes in skin physiology are likely linked to changes in skin microbiota. Here, and in recent studies $[56,57]$, pronounced ontogenetic shifts in bacterial community composition follow metamorphosis. Thus, changes in bacterial assemblages and the reorganization of the immune system during the transition from tadpole to juvenile may facilitate skin colonization by $\mathrm{Bd}$. This might be due to the potential lack of peptide defenses as previously demonstrated for other amphibian species [48, 58]. Here we reported that the composition of the microbial communities is mainly defined by the life stage, and a lower proportion of Bd-inhibitory isolates in juveniles as well as a potential reduction of peptide defenses might explain a higher prevalence in this stage compared with tadpoles and adults. 
Several bacterial morphotypes have demonstrated excellent capabilities of reducing the severity of chytridiomycosis or pathogen growth in vitro [19, 44]. Thus, the presence of bacterial species with antifungal properties is considered one critical factor conferring resistance to $\mathrm{Bd}$. We hypothesized that $D$. labialis and $R$. palmatus could have higher proportions of microorganisms with antifungal properties or a few microbial species with outstanding antiBd capacities, compared with susceptible species. Approximately $86 \%$ of the tested isolates in D. labialis and $76 \%$ in $R$. palmatus inhibited the fungus. The high proportion of culturable bacteria exhibiting anti-Bd properties in this population may be an indication of their importance in host protection, as suggested by Becker et al. [28] for Panamanian amphibians persisting in areas with $\mathrm{Bd}$, where $75 \%$ of the isolates tested exhibited some ability to inhibit $\mathrm{Bd}$ in vitro. Our results are consistent with the idea that symbiotic skin microbes harbored by these two species of Andean frogs are allowing them to cope with the pathogen. In other Andean frogs, differences in susceptibility to $\mathrm{Bd}$ were also associated with proportions of beneficial bacteria [59]. However, it is important to consider that anti-Bd capacity may differ when the bacterium is present in a microbial community on frog skin compared to growth in isolation on standard medium and constant temperature.

Our results, along with other studies, suggest that the range of microbial species with antifungal potential is wider than previously considered [3]. Since various studies have found that some bacterial morphotypes from specific groups (e.g., Pseudomonas, Serratia) are effective inhibitors of the fungal pathogen [27, 60], further research is necessary to determine if these new candidates meet the requirements to be used as probiotics. It is also key to determine the inhibition spectrum of symbiotic bacteria because antifungal capacities may differ among Bd strains [61, 62]. Moreover, variations in the degree of inhibition among bacterial strains belonging to the same species must be examined, since different strains could have different effects on Bd growth [44]. In addition, the anti-Bd function may differ on hosts or in different life stages or microbial communities. This was the case with Janthinobacterium lividum, which has been successfully used in the field to increase survival of the threatened mountain yellow-legged frog in the Sierra Nevada [63]; however, it was not effective on the tropical frog Atelopus zeteki, failing to persist in the skin and to prevent mortality [64]. This demonstrates the urgent need to find local solutions to fight the pathogen. In our study system J. lividum was very rare, with only one isolate out of 615 morphotypes recovered by culture-dependent techniques and only $0.02 \%$ of the OTUs using Illumina.

Several studies have evaluated the association of $\mathrm{Bd}$ related declines and the synthesis of skin defense peptides $[23,24,65]$. Along with symbiotic bacteria, we found that skin defense peptides secreted by the granular glands may contribute to disease resistance. Despite the effectiveness of some peptides killing the fungal pathogen, and the capacity to regulate the growth of different microbes, studies that experimentally evaluate the role of skin defense peptides in structuring microbial communities are lacking. Because we detected differences in the culturable skin-associated bacteria among life stages, we hypothesized that the observed variation might be explained by the differential effect of skin defense peptides on bacteria, either promoting the growth of their own microbiota or impeding colonization from non-native bacteria. For this, we tested the effect of antimicrobial peptides on the growth of bacteria in two ways: inter-species and inter-life stages. Skin defense peptides in this system tended to enhance growth of bacteria found in both amphibian species (Supplementary Figure 7) and only rarely to inhibit it (Fig. 6c) at the concentration tested, while low concentrations of skin defense peptides inhibited Bd growth (Fig. 5). Environmental isolates were not cultured in this study, but one expectation is that the amphibian defense peptides would be more effective at inhibiting growth of microbes that do not tend to colonize the amphibian skin. We hypothesized that the beneficial bacteria in our system may have evolved to survive on host amphibians that share the same environment and thus, resist or even utilize host skin peptides. Although not tested in this study, we suggest that environmental bacteria that could harm or not benefit the amphibian host would be more likely to be inhibited by skin defense peptides. Indeed, Curtobacterium albidum isolated from tadpoles of $R$. palmatus was inhibited by skin peptides and did not display anti-Bd capacity, and might represent a potential pathogen [66]. Although we mostly detected a positive effect of peptides on bacterial growth, additional factors not evaluated in this study (e.g., physiological differences between larvae and adult) might interact with skin defense peptides to determine which microbes can colonize and persist in the skin, leading to the differences observed among life stages.

We found high prevalence of infection in both amphibian species, with around $30 \%$ of the individuals tested being positive for Bd. For these individuals, Bd infection intensity was relatively low, consistent with non-epizootic conditions [51, 67], indicating host resistance mechanisms rather than tolerance of high infection loads. Our study also shows that skin microbial communities and skin defense peptides inhibited the growth of the pathogen and thus, could explain host-pathogen coexistence in these two species of high Andean frogs and may also explain a mechanism for surviving species in other parts of the Andes where epizootics have eliminated many Bd-susceptible species [68, 69]. However, since bacteria and peptides samples were collected in different surveys and from different individuals, we could not test the hypothesis that these two components 
are acting together. In this study, life stage, rather than frog species, was the best predictor of the bacterial community composition. We suggest that integrative studies of multiple defense mechanisms, their interactions, and their variation across life stages (e.g., [70]), such as we present here, are necessary to understand why some species may survive epizootics. By integrating various approaches to untangling complex host-pathogen-microbiota dynamics within a single study system, our research highlights the importance of using a more holistic approach to better understand disease outcomes in diverse species and environments and inform possible mitigation efforts.

Acknowledgements This study was partially completed with financial support from The Rufford Foundation (RSG15305-1 to S.V.F.), Sciences Faculty at Universidad de los Andes (Proyecto Semilla to S.V. F.), the National Science Foundation (1258133 \& 1633948 to V.T.V.). J.G.K. was supported by the University of Massachusetts Boston and the Simons Foundation (429440, WTW). We thank COLCIENCIAS for supporting doctoral studies of S.V.F. A.A.G. was a recipient of "Es Tiempo de volver 2015-2016" postdoctoral fellowship from COLCIENCIAS and the Universidad de La Sabana (Bogotá, Colombia). Procedures for handling animals were approved by the Colombian National Authority under resolution $\mathrm{N}^{\circ} 0528$. For assistance in the field, we thank L.M. Arenas, J. Méndez-Narvaez, P. Palacios, C. Rodríguez, C.M. Betancourth, A. Paz, E. Lasso, R. Márquez, M.E. Cárdenas, E.M. Medina, C. Esquivel, M. González, A.J. Crawford, J. A. Hernández, M. Guevara, C. Sarmiento, M. Anganoy, A. Zarling, J. Sunyer, and D. Galindo. We thank Mr. Mauricio Moreno for allowing us to work at his property. For help in the laboratory, we thank S. Ellison, T. Nguyen, and B. LaBumbard, and for analysis advice, we thank M. Bletz.

\section{Compliance with ethical standards}

Conflict of interest The authors declare that they have no conflict of interest.

\section{References}

1. Zilber-Rosenberg I, Rosenberg E. Role of microorganisms in the evolution of animals and plants: the hologenome theory of evolution. FEMS Microbiol Rev. 2008;32:723-35.

2. Li M, Wang B, Zhang M, Rantalainen M, Wang S, Zhou H, et al. Symbiotic gut microbes modulate human metabolic phenotypes. PNAS. 2008;105:2117-22.

3. Becker MH, Walke JB, Murrill L, Woodhams DC, Reinert LK, Rollins-Smith LA, et al. Phylogenetic distribution of symbiotic bacteria from Panamanian amphibians that inhibit growth of the lethal fungal pathogen Batrachochytrium dendrobatidis. Mol Ecol. 2015a;24:1628-41.

4. Breznak JA, Brune A. Role of microorganisms in the digestion of lignocellulose by termites. J Wild Dis. 2003;39:453-87.

5. Fujimura KE, Slusher NA, Cabana MD, Lynch SV. Role of the gut microbiota in defining human health. Expert Rev Anti Infect Ther. 2010;8:435-54.

6. Fujimura-Yamamoto M, Matsumoto S. Probiotics in prevention of lifestyle disorders. In: Ramakrishna BS, Balakrish Nair G, Takeda Y(eds). Intestinal microbiota and colon cancer. India: Elsevier; 2014. p. $75-83$.
7. Gilbert SF, Sapp J, Tauber AI. A symbiotic view of life: we have never been individuals. Q Rev Biol. 2012;87:325-41.

8. McFall-Ngai M, Hadfield MG, Bosch TCG, Carey HV, DomazetLošo T, Douglas AE, et al. Animals in a bacterial world, a new imperative for the life sciences. PNAS. 2013;110:3229-36.

9. Dong Y, Manfredini F, Dimopoulos G. Implication of the mosquito midgut microbiota in the defense against malaria parasites. PLoS Pathog. 2009;5(5):e1000423.

10. Fisher MC, Henk DA, Briggs CJ, Brownstein JS, Madoff LC, McCraw SL, et al. Emerging fungal threats to animal, plant and ecosystem health. Nature. 2012;484:186-94.

11. Longcore JE, Pessier AP, Nichols DK. Batrachochytrium dendrobatidis gen. et sp. nov., a chytrid pathogenic to amphibians. Mycologia. 1999;91:219-27.

12. Berger L, Speare R, Daszak P, Green DE, Cunningham AA, Goggin CL, et al. Chytridiomycosis causes amphibian mortality associated with population declines in the rain forest of Australia and Central America. PNAS. 1998;95:9031-6.

13. Fisher MC, Garner TWJ, Walker SF. Global emergence of Batrachochytrium dendrobatidis and amphibian chytridiomycosis in space, time, and host. Annu Rev Microbiol. 2009;63:291-10.

14. Skerratt LF, Berger L, Speare R, Cashins SD, McDonald KR, Philott AD, et al. Spread of chytridiomycosis has caused the rapid global decline and extinction of frogs. EcoHealth. 2007;4:125-34.

15. Wake DB, Vredenburg VT. Are we in the midst of the sixth mass extinction? A view from the world of amphibians. PNAS. 2008;105:11466-73.

16. Daszak P, Strieby A, Cunningham AA, Longcore JE, Brown CC, Porter D. Experimental evidence that the bullfrog (Rana catesbeiana) is a potential carrier of chytridiomycosis, an emerging fungal disease of amphibians. Herpetol J. 2004;14:201-7.

17. Reeder NMM, Pessier AP, Vredenburg VT. A reservoir species for the emerging amphibian pathogen Batrachochytrium dendrobatidis thrives in a landscape decimated by disease. PLoS ONE. 2012;7:e33567.

18. Farrer RA, Weinert LA, Bielby J, Garner TWJ, Balloux F, Clare $\mathrm{F}$, et al. Multiple emergences of genetically diverse amphibianinfecting chytrids include a globalized hypervirulent recombinant lineage. PNAS. 2011;108:18732-6.

19. Harris RN, Brucker RM, Walke JB, Becker MH, Schwantes CR, Flaherty DC, et al. Skin microbes on frogs prevent morbidity and mortality caused by a lethal skin fungus. ISME J. 2009a;3:81824.

20. Rollins-Smith LA, Woodhams DC, Reinert LK, Vredenburg VT, Briggs CJ, Nielsen PF, et al. Antimicrobial peptide defenses of the mountain yellow-legged frog (Rana muscosa). Dev Comp Immunol. 2006;30:831-42.

21. Rowley JJL, Alford RA. Hot bodies protect amphibians against chytrid infection in nature. Sci Rep. 2013;3. https://doi.org/10. 1038/srep01515.

22. Rollins-Smith LA, Woodhams DC. Amphibian immunity: staying in tune with the environment. In: Demas GE, Nelson RJ(eds). Ecoimmunology. New York, NY: Oxford University Press; 2012. p. $92-143$.

23. Woodhams DC, Rollins-Smith LA, Carey C, Reinert LK, Tyler MJ, Aford RA. Populational trend associated with skin peptides defenses against chytridiomycosis in Australian frogs. Oecologia. 2006;146:531-40.

24. Woodhams DC, Ardipradja K, Alford RA, Marantelli G, Reinert LK, Rollins-Smith LA. Resistance to chytridiomycosis varies among amphibian species and is correlated with skin peptide defenses. Anim Conserv. 2007a;10:409-17.

25. Harris RN, Lauer A, Simon MA, Banning JL, Alford RA. Addition of antifungal skin bacteria to salamanders ameliorates the effects of chytridiomycosis. Dis Aquat Organ. 2009b;83:11-16. 
26. Kueneman JG, Woodhams DC, Harris R, Archer HM, Knight R, McKenzie VJ. Probiotic treatment restores protection against lethal fungal infection lost during amphibian captivity. Proc R Soc B. 2016;283:20161553.

27. Woodhams DC, Alford RA, Antwis RE, Archer H, Becker MH, Belden LK, et al. Antifungal isolates database of amphibian skinassociated bacteria and function against emerging fungal pathogens. Ecology. 2015;96:595.

28. Becker MH, Walke JB, Cikanek S, Savage AE, Mattheus N, Santiago CN, et al. Composition of symbiotic bacteria predicts survival in Panamanian golden frogs infected with a lethal fungus. Proc R Soc B. 2015b;282:20142881.

29. Bletz MC, Loudon AH, Becker MH, Bell SC, Woodhams DC, Minbiole KPC, et al. Mitigating amphibian chytridiomycosis with bioaugmentation: characteristics of effective probiotics and strategies for their selection and use. Ecol Lett. 2013;16:807-20.

30. Woodhams DC, Bosch J, Briggs CJ, Cashins SD, Davis LR, Lauer A, et al. Mitigating amphibian diseases: strategies to maintain wild populations and control chytridiomycosis. Front Zool. 2011;8:8.

31. Woodhams DC, Bletz M, Kueneman J, McKenzie VJ. Managing amphibian disease with skin microbiota. Trends Microbiol. 2016;24:161-4.

32. Rollins-Smith LA, Carey C, Longcore J, Doersam JK, Boutte A, Bruzgal JE, et al. Activity of antimicrobial skin peptides from ranid frogs against Batrachochytrium dendrobatidis, the chytrid fungus associated with global amphibian declines. Dev Comp Immunol. 2002;26:471-9.

33. Rollins-Smith LA, Carey C, Conlon JM, Reinert LK, Doersam JK, Bergman T, et al. Activities of temporin family peptides against the chytrid Fungus (Batrachochytrium dendrobatidis) associated with global amphibian declines. Antimicrob Agents Chemother. 2003;47:1157-60.

34. Rollins-Smith LA, Conlon JM. Antimicrobial peptide defenses against chytridiomycosis, an emerging infectious disease of amphibian populations. Dev Comp Immunol. 2005;29:589-98.

35. Rollins-Smith LA, Reinert LK, OLeary CJ, Houston LE, Woodhams DC. Antimicrobial peptide defenses in amphibian skin. Inter Comp Biol. 2005;45:137-42.

36. Rollins-Smith LA. The role of amphibian antimicrobial peptides in protection of amphibians from pathogens linked to global amphibian declines. Biochim Biophys Acta. 2009;1788:1593-9.

37. Annis SL, Dastoor FP, Ziel H, Daszak P, Longcore JE. A DNABased assay identifies Batrachochytrium dendrobatidis in amphibians. J Wildl Dis. 2004;40:420-8.

38. Hyatt AD, Boyle DG, Olsen V, Boyle DB, Berger L, Obendorf D, et al. Diagnostic assays and sampling protocols for the detection of Batrachochytrium dendrobatidis. Dis Aquat Organ. 2007;73:175-92.

39. Boyle DG, Boyle DB, Olsen V, Morgan JAT, Hyatt AD. Rapid quantitative detection of chytridiomycosis (Batrachochytrium dendrobatidis) in amphibian samples using real-time Taqman PCR assay. Dis Aquat Organ. 2004;60:141-8.

40. Caporaso JG, Kuczynski J, Stombaugh J, Bittinger K, Bushman FD, Costello EK, et al. QIIME allows analysis of high-throughput community sequencing data. Nat Methods. 2010;7:335-6.

41. Amir A, McDonald D, Navas-Molina JA, Kopylova E, Morton JT, Zech Xu Z, et al. Deblur rapidly resolves single-nucleotide community sequence patterns. mSystems. 2017;2:e00191-16.

42. R Core Team. R: A language and environment for statistical computing. Vienna, Austria: R Foundation for Statistical Computing; 2013. http://www.R-project.org/

43. Segata N, Izard J, Waldron L, Gevers D, Miropolsky L, Garrett WS, et al. Metagenomic biomarker discovery and explanation. Genome Biol. 2011;12(6):R60. https://doi.org/10.1186/gb-201112-6-r60
44. Flechas SV, Sarmiento C, Cárdenas ME, Medina EM, Restrepo S, Amézquita A. Surviving chytridiomycosis: differential antiBatrachochytrium dendrobatidis activity in bacterial isolates from three lowland species of Atelopus. PLoS ONE. 2012;7:e44832.

45. Bell SC, Alford RA, Garland S, Padilla G, Thomas AD. Screening bacterial metabolites for inhibitory effects against Batrachochytrium dendrobatidis using a spectrophotometric assay. Dis Aquat Organ. 2013;103:77-85.

46. Daum JM, Davis LR, Bigler L, Woodhams DC. Hybrid advantage in skin peptide immune defenses of water frogs (Pelophylax esculentus) at risk from emerging pathogens. Infect Genet Evol. 2012;12:1854-64.

47. Flechas SV, Medina EM, Crawford AJ, Sarmiento C, Cárdenas ME, Amézquita A, et al. Characterization of the first Batrachochytrium dendrobatidis isolate from the Colombian Andes, an amphibian biodiversity hotspot. EcoHealth. 2013;10:72-76.

48. Holden WM, Reinert LK, Hanlon SM, Parris MJ, Rollins-Smith LA. Development of antimicrobial peptide defenses of southern leopard frogs, Rana sphenocephala, against the pathogenic chytrid fungus, Batrachochytrium dendrobatidis. Dev Comp Immunol. 2015;48:65-75.

49. Oliveros, JC. VENNY. An interactive tool for comparing lists with Venn Diagrams. 2007. http://bioinfogp.cnnb.csic.es/tools/ venny/index.html.

50. Oksanen J, Blanchet FG, Kindt R, Legendre P, Minchin PR, O'Hara RB, et al. Community ecology package. $R$ package version 2.0-2. 2015. http://CRAN.R-project.org/package=vegan

51. Vredenburg VT, Knapp RA, Tunstall TS, Briggs CJ. Dynamics of an emerging disease drive large-scale amphbian population extinctions. PNAS. 2010;107:9689-94.

52. Kriger KM, Pereoglour F, Hero J-M. Latitudinal variation in the prevalence and intensity of chytrid (Batrachochytrium dendrobatidis) infection in eastern Australia. Conserv Biol. 2007;21:1280-90.

53. Langhammer PF, Burrowes PA, Lips KR, Bryant AB, Collins JP. Susceptibility to the amphibian chytrid fungus varies with ontogeny in the direct-developing frog Eleutherodactylus coqui. J Wildl Dis. 2015;50:438-46.

54. Rollins-Smith LA, Ramsey JP, Pask JD, Reinert LK, Woodhams DC. Amphibian immune defenses against chytridiomycosis: impacts of changing environments. Integr Comp Biol. 2011;51:552-62.

55. Bakar AA, Bower DS, Stockwell MP, Clulow S, Clulow J, Mahony MJ. Susceptibility to disease varies with ontogeny and immunocompetence in a threatened amphibian. Oecologia. 2016;181:997-10091.

56. Kueneman JG, Parfrey LW, Woodhams DC, Archer HM, Knight R, McKenzie VJ. The amphibian skin-associated microbiome across species, space and life history stages. Mol Ecol. 2014;23:1238-50.

57. Prest TL, Kimball AK, Kueneman JG, McKenzie VJ. Hostassociated bacterial community succession during amphibian development. Mol Ecol. 2018;27:1992-2006.

58. Woodhams DC, Bell SC, Bigler L, Caprioli RM, Chaurand P, Lam BA, et al. Life history linked to immune investment in developing amphibians. Conserv Physiol. 2016;4(1):cow025 https://doi.org/10.1093/conphys/cow025

59. Burkart D, Flechas SV, Vredenburg VT, Catenazzi A. Cutaneous bacteria, but not peptides, are associated with chytridiomycosis resistance in Peruvian marsupial frogs. Anim Conserv. 2017;20:483-91.

60. Woodhams DC, LaBumbard BC, Barnhart KL, Becker MH, Bletz MC, Escobar LA, et al. Prodigiosin, violacein, and volatile organic compounds produced by widespread cutaneous bacteria of amphibians can inhibit two Batrachochytrium fungal pathogens. Microb Ecol. 2018;75:1049-62. https://doi.org/10.1007/s00248017-1095-7. 
61. Antwis RE, Preziosi RF, Harrison XA, Garner TWJ. Amphibian symbiotic bacteria do not show universal ability to inhibit growth of the global pandemic lineage of Batrachochytrium dendrobatidis. Appl Environ Microbiol. 2015;81:3706-11.

62. Kearns P, Fischer S, Fernández-Beaskoetxea S, Gabor C, Bosch J, Bowen JL, et al. Fighting fungi with fungi: Antifungal properties of the amphibian mycobiome. Front Microbiol. 2017;8:1-12. https://doi.org/10.3389/fmicb.2017.02494

63. Vredenburg VT, Briggs CJ, Harris RN. Host pathogen dynamics of amphibian chytridiomycosis: the role of the skin microbiome in health and disease. In: Olsen L, Choffnes ER, Relman DA, Pray L (eds). Fungal diseases: an emerging threat to human, animal and plant health. Washington, D.C.: The National Academies Press IOM (Institute of Medicine); 2011. p. 342-55.

64. Becker MH, Harris RN, Minbiole KPC, Schwantes CR, RollinsSmith LA, Reinert LK, et al. Towards a better understanding of the use of probiotics for preventing chytridiomycosis in panamanian golden frogs. EcoHealth. 2011;8:501-6.

65. Woodhams DC, Vredenburg VT, Simon MA, Billheimer D, Shakhtour B, Shyr Y, et al. Symbiotic bacteria contribute to innate immune defenses of the threatened mountain yellow-legged frog Rana muscosa. Biol Conserv. 2007b;138:390-8.

66. Funke G, Aravena-Roman M, Frodl R. First description of Curtobacterium spp. isolated from human clinical specimens. J Clin Microbiol. 2005;43:1032-6.

67. Briggs CJ, Knapp RA, Vredenburg VT. Enzootic and epizootic dynamics of the chytrid fungal pathogen of amphibians. PNAS. 2010;107:9695-700

68. Catenazzi A, Lehr E, Rodriguez LO, Vredenburg VT. Batrachochytrium dendrobatidis and the collapse of anuran species richness and abundance in the upper Manu National Park, Peru. Conser Biol. 2011;25:382-91.

69. Catenazzi A, Swei A, Finkle J, Foreyt E, Wyman L, Vredenburg VT. Epizootic to enzootic transition of a fungal disease in tropical Andean frogs: are surviving species still susceptible? PLoS ONE. 2017;12(10):e0186478.

70. Davis LR, Bigler L, Woodhams DC. Developmental trajectories of amphibian microbiota: response to bacterial therapy depends on initial community structure. Environ Microbiol. 2017;19: 1502-17. 